\title{
Journal of Extension
}

Volume 59 | Number 1

Article 3

3-11-2021

\section{Young Cattle Producers Conference Develops Leaders in Idaho}

\author{
Carmen J. Willmore \\ University of Idaho, cwillmore@uidaho.edu \\ Meranda Small \\ University of Idaho, msmall@uidaho.edu \\ Sarah Baker \\ University of Idaho, sdbaker@uidaho.edu \\ Jim Church \\ University of Idaho, jchurch@uidaho.edu
}

\section{cc) (1) (2)}

This work is licensed under a Creative Commons Attribution-Noncommercial-Share Alike 4.0 License.

\section{Recommended Citation}

Willmore, C. J., Small, M., Baker, S., \& Church, J. (2021). Young Cattle Producers Conference Develops Leaders in Idaho. Journal of Extension, 59(1). https://doi.org/10.34068/joe.59.01.03

This Ideas at Work is brought to you for free and open access by TigerPrints. It has been accepted for inclusion in Journal of Extension by an authorized editor of TigerPrints. For more information, please contact kokeefe@clemson.edu. 


\title{
Young Cattle Producer Conference Develops Leaders in Idaho
}

\author{
Carmen Willmore ${ }^{1}$, Meranda Small ${ }^{2}$, Sarah Baker $^{3}$, and Jim Church $^{4}$
}

AUTHORS: ${ }^{1}$ University of Idaho Extension-Lincoln County, University of Idaho. ${ }^{2}$ University of Idaho Extension-Bingham County, University of Idaho. ${ }^{3}$ University of Idaho Extension-Custer County, University of Idaho. ${ }^{4}$ University of Idaho Extension-Idaho County, University of Idaho.

\begin{abstract}
The need for young leadership in the beef industry has become a rising concern as the average age of primary operators increases. Idaho Extension educators developed a leadership conference for beef producers, with the primary objective being to educate and develop leadership qualities in young cattle producers. Participants, aged 18-40 years old, have opportunities to learn all aspects of the industry through presentations, hands-on learning, and industry tours. A postconference survey revealed that participants had a better understanding of the beef industry at the conclusion of the program and planned to use what they learned. Extension professionals elsewhere can use our description of the program to build similar programs in their states.
\end{abstract}

\section{INTRODUCTION}

Over the past 30 years, the average age of farm operators in the United States has been increasing (National Agricultural Statistics Service [NASS], 2012). Data from the 2012 U.S. Census of Agriculture indicate that at the time only $6 \%$ of primary operators were under 35 years old, $61 \%$ were 35 to 64 years old, and $33 \%$ were 65 years and older (NASS, 2012). Of those operators in the 35-64 age group, 608,052, the highest proportion, were in the 55-64 range, followed by 466,036 in the 45-54 range and then 214,016 in the 35-44 range (NASS, 2012). Seeing declines in the numbers of young producers, stakeholders at national and state levels have developed education programs targeted specifically to young cattle producers. For example, the National Cattlemen's Beef Association (NCBA) has hosted a weeklong young cattlemen's conference with the objective of developing future leaders for the beef industry (NCBA, 2020). The NCBA's young cattlemen's conference includes tours of packing facilities, feedlots, and ranches as well as time spent with industry leaders as participants move through different areas of the country. Having observed the decline in young producers in Idaho and the program hosted by the NCBA, a committee of representatives from the Idaho Cattle Association (ICA) and University of Idaho (UI) developed a leadership conference to prepare young producers for careers in the cattle industry specific to Idaho. Extension professionals elsewhere can use information provided herein to do the same in their states.

\section{EDUCATIONAL NEED}

In 2015, UI administration charged Department of Animal, Veterinary, and Food Sciences and Extension faculty with developing a Beef Program of Distinction (Beef POD). The Beef POD leaders hosted listening sessions around the state wherein producers and industry representatives provided input regarding their needs. Through these sessions, a need for educating young beef producers about the industry and providing resources to help them make better business and management decisions was identified. A committee of Extension faculty (including the members of our author team), beef cattle producers, and allied industry representatives formed to develop the 3-day Young Cattle Producer Conference (YCC). 


\section{Willmore, Baker, Church, and Small}

\section{PROGRAM DESCRIPTION}

The 3-day conference includes 20 participants aged 18-40. Participants are nominated or self-nominated and selected by our committee. Selection is based on the applicant's current involvement in the industry and past experiences in leadership positions and recommendations by peers.

The primary objective of the YCC is to engage young producers with leaders of Idaho's cattle industry. Activities across the 3 days are intended to address this objective.

The first session, The Beef Cattle Industry in Idaho, includes representatives from the packer, feedlot, stocker, commercial cow-calf, and purebred sectors who speak on their experiences. Presentations are 30 min in length and are followed by discussion with the conference participants. The first session concludes with a meat cutting demonstration, addressing an aspect of the retail side of beef production.

The second day of the YCC begins with a session on current issues facing young cattle producers. During this session, participants learn about financing of a cattle operation, risk management tools, herd health, and public lands issues. This session gives participants a chance to meet representatives of various agencies related to agriculture, including the Public Lands Council, Farm Credit Services, and the Idaho State Department of Agriculture. Organization representatives describe ways their resources can help attendees in development of their cattle operations.

To experience increased exposure to all aspects of the industry, the class tours local ranches on the afternoon of the second day, spending $1 \mathrm{hr}$ at each location. Participants tour a cow-calf operation, custom packing facility, feedlot, and purebred operation. Many of the businesses spotlighted have been in the beef industry for over 30 years. This circumstance leads to discussions about how the industry has transitioned over the years and how new technologies make operations more efficient. The tour concludes with a discussion of what participants plan to do differently when they return to their own operations as a result of participating in the YCC program.

The final session, on the morning of the third day, addresses how to become more involved in the industry. Speakers have included members of a local Farm Bureau's Young Farmer and Rancher Committee, ICA, Idaho Beef Council, and Rangeland Resource Commission. The theme of these presentations is how these local organizations and commissions support ranchers in their communities, the state, and the nation. At the conclusion of the final session, participants are presented with a YCC graduation certificate and asked to fill out a program evaluation survey. The evaluation addresses how participants view the topics covered and the program overall.

In the first year of the program, grant funds from the UI Beef POD supported travel and hotel accommodations for the participants. Since then, sponsorships from industry and coordination of the meeting with the ICA summer meeting have helped reduce costs and finance conference rooms and other expenses. This change has allowed us to host the conference free of charge to participants.

\section{PROGRAM OUTCOME AND IMPACTS}

A common remark in the survey results relates to length and timing of the conference. Participants positively review the program; however, some have mentioned that finding time to leave their operations for a 3-day conference is challenging. This circumstance is not unusual. A North Dakota beef industry survey indicated that 67.9\% of producers were not attending North Dakota State University Extension meetings because of lack of time (Dahlen et al., 2014). Similarly, in the first 3 years of the YCC, some participants enrolled for the conference but at the last minute were unable to attend. Though conference length is a concern, we feel that the face-to-face aspect of the meeting and duration of the program are necessary for meeting the objectives of building connections and facilitating leadership development. Additionally, the North Dakota survey showed that $59 \%$ of the information respondents were most likely to receive from Extension occurred in face-to-face meetings (Dahlen et al., 2014).

Results of the YCC evaluations suggest that participants find the program beneficial (Table 1). For example, participants have indicated having a better understanding of the beef industry and being likely to use what they learned and become more involved in groups affiliated with the industry. Similar results were observed for Washington State University beef education programs in 2016, where 75\% of beef producers indicated that they would be very likely to or without a doubt would apply information learned at Extension conferences to their operations (Nelson \& Llewellyn, 2018). YCC attendees also rated highly the quality of the speakers and information presented $(M=4.7 / 5.0)$ 


\section{Young Cattle Producer Conference Develops Leaders in Idaho}

Table 1. Participant Views of Their Experiences and Future Goals Related to Idaho's Young Cattle Producers Conference

\begin{tabular}{lc}
\hline \multicolumn{1}{c}{ Survey question } & M \\
\hline $\begin{array}{l}\text { How much better of an understanding do you have of the beef } \\
\text { industry in Idaho at the end of the conference? }\end{array}$ & 4.3 \\
$\begin{array}{l}\text { How likely are you to utilize what you learned about current issues } \\
\text { facing young producers? }\end{array}$ & 4.7 \\
$\begin{array}{l}\text { How likely are you to become more involved in groups affiliated } \\
\text { with the beef industry? }\end{array}$ & 4.2 \\
$\begin{array}{l}\text { Will what you learned and experienced provide economic value to } \\
\text { your operation? }\end{array}$ & 4.9 \\
$\begin{array}{l}\text { Do you intend to put any of what you learned to use in your } \\
\text { operation? }\end{array}$
\end{tabular}

Note. Scaled response options ranged from 1 (not at all) to 5 (a lot or very likely).

\section{CONCLUSION}

Based on positive survey responses from the past 3 years, UI will continue to offer the YCC program. The information shared at this conference is meeting needs of Idaho's young producers and facilitates their potential for longevity within the industry. An essential aspect of the program is the inclusion of successful ranchers and cattle industry leaders as speakers and teachers. Involving state leaders links our state's young producers to the "movers and shakers" of Idaho's cattle industry. The location of the conference will rotate around the state, enabling us to reach many young producers and thus make the largest impact possible. Plans to conduct and report results from a more extensive evaluation of the program in the future are underway. Extension professionals elsewhere can use our description of the program framework to build leadership programs in their own states.

\section{REFERENCES}

Dahlen, C. R., Hadrich, J. C., \& Lardy, G. P. (2014). The North Dakota beef industry survey: Implications for Extension. Journal of Extension, 52(6), Article v52-6rb7. https://www.joe.org/joe/2014december/rb7.php National Agricultural Statistics Service. (2012). Census of agriculture. U.S. Department of Agriculture.

National Cattlemen's Beef Association. (2020). Young cattlemen's conference. https://www.ncba.org/youngcattlemensconference.aspx

Nelson, M. L., \& Llewellyn, D. (2018). Do beef production conferences affect beef producers' perceptions of applied research and Extension programs? Journal of Extension, 56(3), Article v56-3rb2. https://www.joe.org/ joe/2018june/rb2.php 